\title{
Efficiency Factor and Modulus of Elasticity of Lightweight Concrete with Expanded Clay Aggregate
}

\section{Fator de Eficiência e Módulo de Elasticidade do Concreto Leve com Argila Expandida}
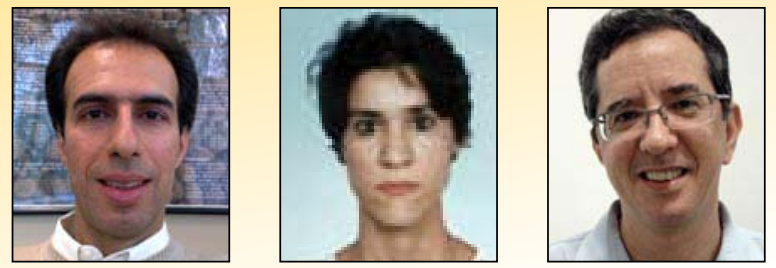

W.G MORAVIA a

moravia@civil.cefetmg.br

A. G. GUMIERI b adriana@demc.ufmg.br

W. L. VASCONCELOS

wlv@demet.ufmg.br

\begin{abstract}
Nowadays lightweight concrete is used on a large scale for structural purposes and to reduce the self-weight of structures. Specific gravity, compressive strength, strength/weight ratio and modulus of elasticity are important factors in the mechanical behavior of structures. This work studies these properties in lightweight aggregate concrete (LWAC) and normal-weight concrete (NWC), comparing them. Specific gravity was evaluated in the fresh and hardened states. Four mixture proportions were adopted to evaluate compressive strength. For each proposed mixture proportion of the two concretes, cylindrical specimens were molded and tested at ages of 3,7 and 28 days. The modulus of elasticity of the NWC and LWAC was analyzed by static, dynamic and empirical methods. The results show a larger strength/ weight ratio for LWAC, although this concrete presented lower compressive strength.
\end{abstract}

Keywords: lightweight concrete, efficiency factor, modulus of elasticity.

\section{Resumo}

O concreto leve e bastante utilizado com a finalidade estrutural para redução do peso próprio de estruturas de concreto armado. Massa específica, resistência à compressão, relação resistência/peso, e módulo de elasticidade são fatores importantes quando se avalia o comportamento mecânico de estruturas. Este trabalho analisou estas propriedades no concreto leve (LWC) e comparou-as com as do concreto convencional (NWC). A massa específica dos concretos foi avaliada no estado fresco e no estado endurecido. Foram adotados quatro traços de dosagem para avaliar a resistência à compressão. Para cada traço de dosagem adotado e cada tipo de concreto, foram moldados corpos-de-prova cilíndricos que foram rompidos aos 3, 7 e 28 dias de idade. O módulo de elasticidade do concreto leve e do concreto convencional foram avaliados pelos métodos estático, dinâmico, e empírico. Os resultado mostraram uma melhor relação resistência/peso para o concreto leve, apesar deste tipo de concreto ter apresentado menor resistência à compressão.

Palavras-chave: concreto leve, fator de eficiência, módulo de elasticidade.

\footnotetext{
${ }^{a}$ Weber Guadagnin Moravia - Department of Civil Engineering at the Federal Center for Technological Education of Minas Gerais.

${ }^{b}$ Adriana Guerra Gumieri - Department of Materials Engineering and Construction at Federal University of Minas Gerais.

c Wander Luiz Vasconcelos - Department of Metallurgic Engineering and Materials at Federal University of Minas Gerais.
} 


\section{Introduction}

The low strength/weight ratio of concrete when compared to that of steel is a disadvantage in construction. To improve this ratio, the specific gravity of concrete can be reduced or its strength increased. In the last few decades, the specific gravity of concrete has been reduced successfully through the use of lightweight concrete.

There are three types of lightweight concrete whose densities are reduced by specific methods. Aired concrete or cellular concrete is produced by introducing voids formed by gas bubbles inside the concrete mass. Concrete without fines is concrete that does not contain fine aggregates, which leads to the formation of numerous air voids. Lightweight aggregate concrete (LWAC) is obtained using a porous aggregate of low specific gravity in place of conventional aggregate [1].

LWAC is used more frequently than other types of lightweight concrete due to the great variety of low density aggregates, which allows for the production of concretes with different properties. Moreover, LWAC has higher mechanical strength than other types of lightweight concrete, allowing for its use as structural concrete. Expanded clay can be used as an aggregate in the production of lightweight concrete due to its low density. This aggregate is produced from several types of clay that expand during thermal treatment due to the decomposition of some of their components and the consequent formation of gases that remain trapped inside the viscous mass of the clay during its coalition $[1,2]$. Due to the increasing shortage of conventional aggregates, expanded clay offers an important alternative for the production of concretes.

Expanded clay with a maximum characteristic dimension of $19 \mathrm{~mm}$ is recommended for lightweight structural concrete. Smaller expanded clay grains present a higher apparent specific mass, and hence higher mechanical strength due to the lower volume of voids. In addition, in the case of more fluid concretes, expanded clay with smaller dimensions provides lower segregation by flotation of the coarse aggregate [3].

Casting control prevents bleeding and segregation of materials, avoiding the concentration of coarse aggregates at the bottom of concrete components and an upper surface composed mostly of mortar. This control can improve the interface between the coarse aggregate and the cement matrix of concretes. There is a consensus in the literature that the transition zone constitutes weak points in the structure of concretes, clearly influencing their mechanical strength, elasticity modulus and permeability [4].

Due to its porous surface, expanded clay can promote stronger adherence between the aggregate and the cementitious matrix. The water absorbed by aggregates during the concrete mixing procedure becomes available to hydrate the cement and a large part of additional hydration takes place at the aggregate/matrix interface [5]

This work evaluates the mechanical properties of lightweight concrete produced with expanded clay, analyzing its compressive strength, pozzolanic activity, modulus of elasticity, and the efficiency factor (mechanical strength vs. density).

\section{Materials and experimental program}

In the present work, an expanded clay characterized by [6] was used as coarse aggregate in LWAC, and a limestone with a particle size distribution compatible with that of the expanded clay was used in normal-weight concrete (NWC). The fine aggregate was washed natural quartz sand with a fineness modulus of 2.18, matching the lower usable zone (1.55 to 2.20), according to the Brazilian NBR 7211 standard [7]. This size was chosen because it provides smaller segregation of the expanded clay in LWAC. This can be explained by the higher surface area of finer sands, which results in an increased consumption of water and cement, promoting more cohesive mixtures [8].

The cement used in the concretes was Portland CPV cement, which corresponds to the ASTM C 150 (CP III) cement, whose main characteristic is its high initial strength. This type of cement was chosen because it does not contain mineral admixtures such as blast furnace slag or pozzolans.

\subsection{Mixture proportions method}

The proportions of the concrete mixtures were determined according to the IPT/USP method [9]. This method is based on obtaining concrete proportions that provide the desired consistence and an average compressive strength ( $\mathrm{fcj}$ ) at $\mathrm{j}$ days of age. The traces were dosed for estimated strengths of 20 to $40 \mathrm{MPa}$ (4 traces) at 28 days of age. The lower limit corresponds to the minimum strength for structural purposes, while the upper limit approaches the maximum values obtained for the compressive strength of lightweight concrete. A mortar content of $60 \%$ was used as the dosage parameter for both concretes. The initial trace was dosed for NWC, determining the quantity of coarse aggregate (crushed limestone) in mass (Table 3). A conversion was then made of mass to volume of crushed limestone, and the same volume of expanded clay was adopted for the trace of the LWAC, due to the difference in the densities of expanded clay and crushed limestone.

\subsection{Analysis of compressive strength and density}

The compressive strength of four mixture proportions was evaluated. Cylindrical specimens were molded $(10 \mathrm{~cm}$ diameter and 20 $\mathrm{cm}$ height) of each mixture proportion of the two concretes, as recommended by the Brazilian NBR 5738 [10] standard. The specimens were cured in a moist room and tested at the ages of 3,7 and 28 days, as specified by the NBR 5739 [11] standard, which corresponds to the American ASTM C 39 standard.

After molding, the density of the NWC and the LWAC was measured in the fresh state. The density of the concrete in the hardened state was determined from the mass-to-volume ratio of the specimen at the ages of 3,7 and 28 days.

\subsection{Pozzolanic activity test}

The pozzolanic activity of the dust adhering to the surface of the expanded clay in contact with the Portland CPV ARI cement was evaluated by a chemical method. This method evaluates the pozzolanic activity by comparing the amount of calcium hydroxide $(\mathrm{CH})$ present in the liquid phase in contact with the moisturized cement and the amount of $\mathrm{CH}$ that could saturate an excipient of the same alkalinity, as recommended by the NBR 5753 [12] standard.

\subsection{Scanning electron microscopy (SEM)}

The morphology of the expanded clay and the transition zone between the expanded clay and the cement matrix was analyzed microstruc- 


\section{Table 1 - Physical characterization of the aggregates}

\begin{tabular}{lccc|}
\multicolumn{1}{c}{ Parameters } & Sand & $\begin{array}{c}\text { Crushed } \\
\text { limestone }\end{array}$ & Expanded clay \\
\hline Fineness modulus & 2.18 & 6.48 & 6.48 \\
Maximum characteristic dimension $(\mathrm{mm})$ & 2.40 & 19 & 19 \\
Specific mass $\left(\mathrm{g} / \mathrm{cm}^{3}\right)$ & 2.58 & 2.68 & 2.57 \\
Unitary mass $\left(\mathrm{kg} / \mathrm{m}^{3}\right)$ & 1.40 & 1.64 & 0.46 \\
\hline
\end{tabular}

turally by scanning electron microscopy (SEM, JSM-80 PHILIPS), using samples coated with a carbon film to render them conductive. The images were obtained by secondary electron imaging.

\subsection{Modulus of elasticity}

The static modulus of elasticity, which corresponds to the secant modulus, was determined for both concretes. The secant modulus is determined based on the slope of a straight line drawn from the origin to a point of the stress vs. deformation curve that corresponds to $40 \%$ of the rupture stress in cylindrical specimens, as recommended by the NBR 8522 [13] standard, which corresponds to the ASTM C 469 standard. Three specimens of each proportion and type of concrete were analyzed at 28 days of age.

The dynamic modulus of elasticity of the concretes (Young's modulus) was determined from the measure of the resonance frequency (transverse) of NWC and LWAC specimens, according to the ASTM C 215 standard. This modulus was determined from 3 cylindrical specimens (10 cm diameter and $20 \mathrm{~cm}$ height) of each proportion at 28 days of age.

The modulus of elasticity was also determined from the empirical formula proposed by the ACI 318 [14] commission, as specified below. Equation [1], which relates the modulus of elasticity with the compressive strength of the concrete, was chosen because it also takes into account the density of the material.

$$
E_{c}=43 \times 10^{-3} \rho^{1,5} \sqrt{f_{c}}
$$

where:

$E_{c}$ - modulus of elasticity (GPa);

$f_{c}$ - compressive strength (MPa);

$\rho$ - density $\left(\mathrm{kg} / \mathrm{m}^{3}\right)$.

\section{Results and Discussion}

\section{Characterization}

Table [1] presents the Maximum Characteristic Dimension, the Fineness Modulus, and the densities of the aggregates.

Table [2] presents the physical characteristics and the results of the chemical analysis of the cement used in the production of the concretes.
The percentages of oxides determined in the chemical analysis of the cement fall within the limits established by the Brazilian NBR 5733 standard - High initial strength Portland cement.

\subsection{Mixture proportions}

Table [3] shows the proportions, the consumption of materials in mass per cubic meter of concrete, and the results obtained in the slump test, while Figure [1] shows the dosage diagram for the NWC.

In general, the reduction of slump in LWAC was higher than that obtained for NWC. The slump increased as the estimated strength increased, due to the higher consumption of cement and, hence, the larger amount of paste surrounding the aggregates. A difference was expected in the values of consistency of the two types of concrete due to the stronger influence of gravity on conventional aggregates. However, the values obtained in the LWAC slump test approached those of NWC. The higher consistency of the LWAC can be attributed to the rounded shape of the expanded clay grains, which increase the workability of concretes.

\subsection{Density of the concrete in the fresh and hardened state}

Table [4] lists the NWC and LWAC density values. According to the ASTM C 330 [15] standard, the specific gravity of structural LWAC concrete in the dry state should not exceed $1850 \mathrm{~kg} / \mathrm{m}^{3}$, usually ranging from 1400 to $1800 \mathrm{~kg} / \mathrm{m}^{3}$. Lightweight insulating concrete (non-structural function) usually has a specific gravity of less than $800 \mathrm{~kg} / \mathrm{m}^{3}$.

The LWAC analyzed in this study can be classified as structural, based on its values of specific gravity. The specific gravity of the concretes was also found to be directly proportional to their compressive strength.

\subsection{Compressive strength}

Table [5] lists the results of the axial compressive strength of the concretes evaluated at the ages of 3,7 and 28 days.

Figure [2] presents the results of axial compressive strength as a function of the age of the concrete specimens analyzed.

The LWAC showed a reduction of $22 \%$ to $28 \%$ of compressive strength compared with that of the NWC. The decrease in the 


\section{Table 2 - Physicochemical characterization of Portland CPV cement}

\section{Physical characteristics}

$\begin{array}{lc}\text { Filler density }\left(\mathrm{kg} / \mathrm{dm}^{3}\right) & 0.92 \\ \text { Specific mass }\left(\mathrm{g} / \mathrm{cm}^{3}\right) & 3.26 \\ \text { Fineness - no. } 200 \text { sieve }(\%) & 2.0 \\ \text { Initial setting time (min.) } & 160 \\ \text { Final setting time (min.) } & 240 \\ \text { Compressive strength at } 3 \text { days(MPa) } & 36.8 \\ \text { Compressive strength at } 7 \text { days(MPa) } & 43.3 \\ \text { Compressive strength at } 28 \text { days(MPa) } & 47.1\end{array}$

\section{Chemical Analysis}

$\begin{array}{cr}\text { Oxides } & \text { Content } \\ \mathrm{CaO} & 67.13 \\ \mathrm{SiO}_{2} & 19.34 \\ \mathrm{Al}_{2} \mathrm{O}_{3} & 3.13 \\ \mathrm{Fe}_{2} \mathrm{O}_{3} & 2.67 \\ \mathrm{FeO} & 0.04 \\ \mathrm{MgO} & 0.52 \\ \mathrm{P}_{2} \mathrm{O}_{5} & 1.10 \\ \mathrm{~K}_{2} \mathrm{O} & 0.68 \\ \mathrm{Na}_{2} \mathrm{O} & 0.02 \\ \mathrm{PPC} & 3.32\end{array}$

Table 3 - Proportions and consumption of materials per cubic meter of concrete

\begin{tabular}{|c|c|c|c|c|c|c|c|}
\hline $\begin{array}{l}\text { Estimated } \\
\text { Compressive } \\
\text { Strength } \\
\text { (MPa) }\end{array}$ & Concrete & $\begin{array}{c}\text { Mix } \\
\text { Proportion } \\
\text { (weight) }\end{array}$ & $\begin{array}{l}\text { Portland } \\
\text { Cement } \\
\left(\mathrm{kg} / \mathrm{m}^{3}\right)\end{array}$ & $\begin{array}{c}\text { Fine } \\
\text { aggregate } \\
\left(\mathrm{kg} / \mathrm{m}^{3}\right)\end{array}$ & $\begin{array}{l}\text { Coarse } \\
\text { aggregate } \\
\left(\mathrm{kg} / \mathrm{m}^{3}\right)\end{array}$ & $w / C$ & $\begin{array}{l}\text { Slump } \\
(\mathrm{mm})\end{array}$ \\
\hline \multirow{2}{*}{20} & NWC & $1: 3.21: 2.79$ & \multirow{2}{*}{373} & \multirow{2}{*}{1197} & 1042 & \multirow{2}{*}{0.63} & 85 \\
\hline & LWAC & 1:3.21:0.79 & & & 293 & & 75 \\
\hline \multirow{2}{*}{25} & NWC & 1:1.99:2.24 & \multirow{2}{*}{465} & \multirow{2}{*}{925} & 1042 & \multirow{2}{*}{0.55} & 140 \\
\hline & LWAC & $1: 1.99: 0.63$ & & & 293 & & 165 \\
\hline \multirow{2}{*}{30} & NWC & $1: 1.40: 1.80$ & \multirow{2}{*}{579} & \multirow{2}{*}{811} & 1042 & \multirow{2}{*}{0.48} & 165 \\
\hline & LWAC & $1: 1.40: 0.51$ & & & 293 & & 170 \\
\hline \multirow{2}{*}{40} & NWC & $1: 1.10: 1.59$ & \multirow{2}{*}{655} & \multirow{2}{*}{720} & 1042 & \multirow{2}{*}{0.41} & 174 \\
\hline & LWAC & $1: 1.10: 0.45$ & & & 293 & & 180 \\
\hline
\end{tabular}




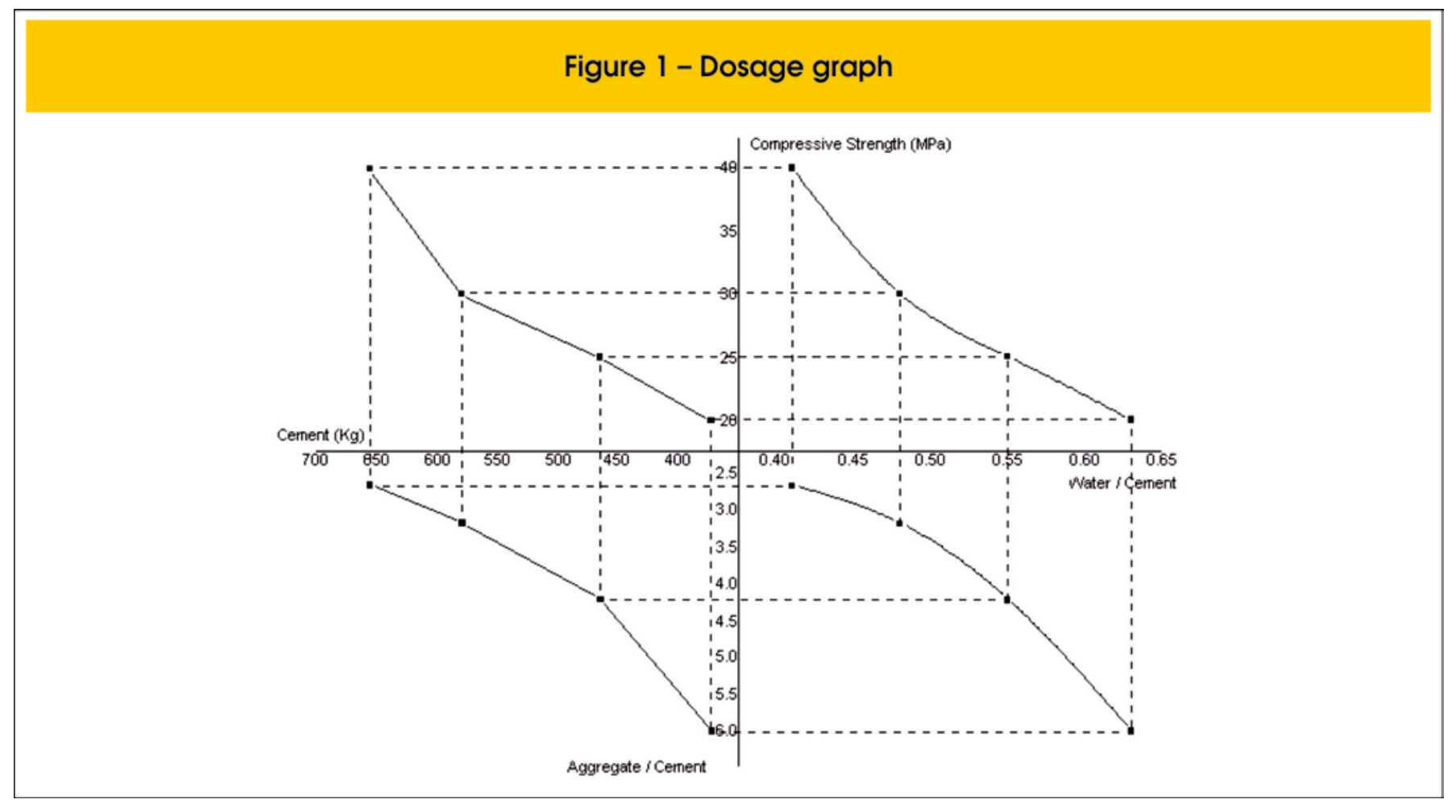

Table 4 - Density of the analyzed concretes

\begin{tabular}{|c|c|c|c|c|c|}
\hline \multicolumn{6}{|c|}{ Density of the concretes $\left(\mathrm{kg} / \mathrm{m}^{3}\right)$} \\
\hline \multirow{2}{*}{$\begin{array}{l}\text { Mixture } \\
\text { Proportions } \\
\text { (MPa) }\end{array}$} & \multirow[b]{2}{*}{ Concrete } & \multirow[b]{2}{*}{ Fresh } & \multicolumn{3}{|c|}{ Age (days) } \\
\hline & & & 3 & 7 & 28 \\
\hline \multirow{2}{*}{20} & NWC & 2325 & 2312 & 2293 & 2293 \\
\hline & LWAC & 1635 & 1617 & 1603 & 1571 \\
\hline \multirow{2}{*}{25} & NWC & 2336 & 2327 & 2327 & 2325 \\
\hline & LWAC & 1621 & 1620 & 1615 & 1604 \\
\hline \multirow{2}{*}{30} & NWC & 2386 & 2352 & 2350 & 2340 \\
\hline & LWAC & 1634 & 1622 & 1618 & 1611 \\
\hline \multirow{2}{*}{40} & NWC & 2431 & 2346 & 2367 & 2410 \\
\hline & LWAC & 1652 & 1614 & 1641 & 1645 \\
\hline
\end{tabular}

strength of LWAC was found to be higher in the concrete with an estimated compressive strength of $40 \mathrm{MPa}$. The higher decrease in strength in this mixture proportion can be explained by the lower strength of the lightweight aggregate. According to the ASTM C 330 [15] standard, lightweight structural concrete should have a compressive strength of more than $17 \mathrm{MPa}$ at 28 days of age, determined by the rupture of the axial compression of the cylindrical specimen. However, the Brazilian NBR 6118 [16] standard specifies minimum values of $20 \mathrm{MPa}$ for structural concretes, without specifying values for lightweight concrete. Although its mechanical strength decreased, the lightweight concrete reached the strength specified by both the American and Brazilian standards; this strength is specified only for concrete dosed for 20 and $25 \mathrm{MPa}$.

\subsection{Efficiency factor}

Figure [3] illustrates the efficiency factor of NWC and LWAC for an estimated compressive strength of $40 \mathrm{MPa}$, which was determined from the ratio of mechanical strength to density of each concrete. Table [6] lists the values used to calculate the efficiency factors and the rates of evolution of the properties of the concretes as a function of age. 
Most of the materials showed a directly proportional relationship between mechanical resistance and density. Despite its lower compressive strength, the LWAC showed a higher efficiency factor due to the higher proportion of its decrease in density when compared with that of the NWC.

The efficiency factor of the LWAC obtained at 3,7 and 28 days of age was $20 \%, 15 \%$ and $8 \%$ higher, respectively, than that of the NWC. The difference between the efficiency factors of the concretes were found to decrease with increasing age. The compres- sive strength of the NWC showed a $10 \%$ increase at 7 days and a $38 \%$ increased at 28 days when compared to the average strength obtained at the age of 3 days. Similarly, the LWAC showed an increase in compressive strength of $6 \%$ at 7 days and of $23 \%$ at 28 days compared to its strength at 3 days of age. Therefore, the NWC showed a higher gain in strength. With regard to density, the NWC showed an increase of $0.9 \%$ at 7 days and of $2.73 \%$ at 28 days compared to that a 3 days. On the other hand, the density of LWAC increased by $1.67 \%$ and $1.92 \%$ at the same ages, indicat-

Table 5 - Axial compressive strength of the concretes

\begin{tabular}{|c|c|c|c|c|c|c|c|c|c|c|}
\hline \multirow{3}{*}{$\begin{array}{l}\text { Estimated } \\
\text { Compressive } \\
\text { Strength } \\
\text { (MPa) }\end{array}$} & \multirow{3}{*}{ Concrete } & & & & & & & & & \\
\hline & & \multicolumn{9}{|c|}{ Compressive strength (MPa) } \\
\hline & & 3 days & Avg & SD & 7 days & Avg & SD & 28 days & Avg & SD \\
\hline \multirow{6}{*}{20} & \multirow{3}{*}{ NWC } & 18.2 & \multirow{3}{*}{18.6} & \multirow{3}{*}{0.4} & 20.0 & \multirow{3}{*}{20.6} & \multirow{3}{*}{0.8} & 23.1 & \multirow{3}{*}{22.7} & \multirow{3}{*}{0.6} \\
\hline & & 18.5 & & & 20.2 & & & 22.0 & & \\
\hline & & 19.0 & & & 21.5 & & & 23.0 & & \\
\hline & & 12.5 & \multirow{3}{*}{13.5} & \multirow{3}{*}{1.4} & 17.1 & \multirow{3}{*}{16.3} & \multirow{3}{*}{1.2} & 15.5 & \multirow{3}{*}{17.6} & \multirow{3}{*}{1.9} \\
\hline & \multirow[t]{2}{*}{ LWAC } & $8.7^{\star}$ & & & 14.9 & & & 19.3 & & \\
\hline & & 14.5 & & & 17.0 & & & 18.0 & & \\
\hline \multirow{6}{*}{25} & \multirow{4}{*}{ NWC } & 21.2 & \multirow{4}{*}{20.9} & \multirow{4}{*}{0.4} & 22.3 & \multirow{4}{*}{22.4} & \multirow{3}{*}{0.6} & 26.3 & \multirow{3}{*}{26.0} & \multirow{3}{*}{0.7} \\
\hline & & 21.0 & & & 21.9 & & & 26.4 & & \\
\hline & & 20.4 & & & 23.1 & & & 25.2 & & \\
\hline & & 14.9 & & & 16.6 & & & 18.4 & & \\
\hline & \multirow[t]{2}{*}{ LWAC } & 15.5 & \multirow[t]{2}{*}{15.1} & \multirow[t]{2}{*}{0.3} & 18.6 & \multirow[t]{2}{*}{17.6} & 1.0 & 18.2 & 18.9 & 1.0 \\
\hline & & 15.0 & & & 17.5 & & & 20.1 & & \\
\hline & & 24.3 & & & 26.1 & & & 28.6 & & \\
\hline & NWC & 23.6 & 24.0 & 0.4 & 28.3 & 27.1 & 1.1 & $25.3^{*}$ & 28.1 & 2.5 \\
\hline 30 & & 24.0 & & & 26.8 & & & 30.4 & & \\
\hline 30 & & 13.4 & & & $12.3^{*}$ & & & 20.5 & & \\
\hline & LWAC & 17.3 & 15.4 & 2.7 & 18.2 & 19.9 & 2.4 & 21.7 & 21.8 & 1.4 \\
\hline & & $9.0^{*}$ & & & 21.6 & & & 23.3 & & \\
\hline & & 32.8 & & & 37.5 & & & 46.5 & & \\
\hline & NWC & 30.8 & 32.5 & 1.6 & 34.3 & 35.9 & 2.3 & 43.2 & 44.9 & 2.3 \\
\hline$\Delta \cap$ & & 33.9 & & & $44.6^{\star}$ & & & $50.2^{*}$ & & \\
\hline 70 & & 28.4 & & & 26.9 & & & 30.2 & & \\
\hline & LWAC & 27.3 & 26.9 & 1.7 & 28.9 & 28.6 & 1.6 & 35.4 & 33.2 & 2.6 \\
\hline & & 25.0 & & & 30.0 & & & 34.0 & & \\
\hline
\end{tabular}


ing a higher gain in the density of the NWC. Because the NWC showed a higher rate of increase in strength than in density, and because this rate was also higher than the strength increase rate

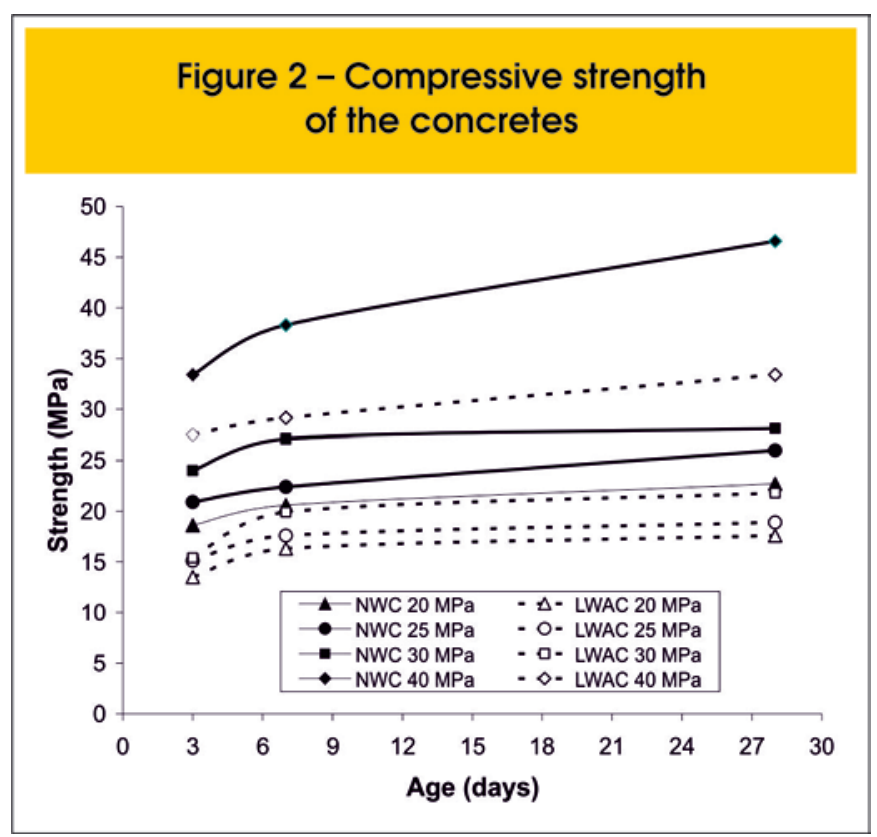

of the LWAC, the NWC showed an increase in the efficiency factor with age, reducing the difference in relation to the efficiency factor of the LWAC. This indicates that the efficiency curves of the

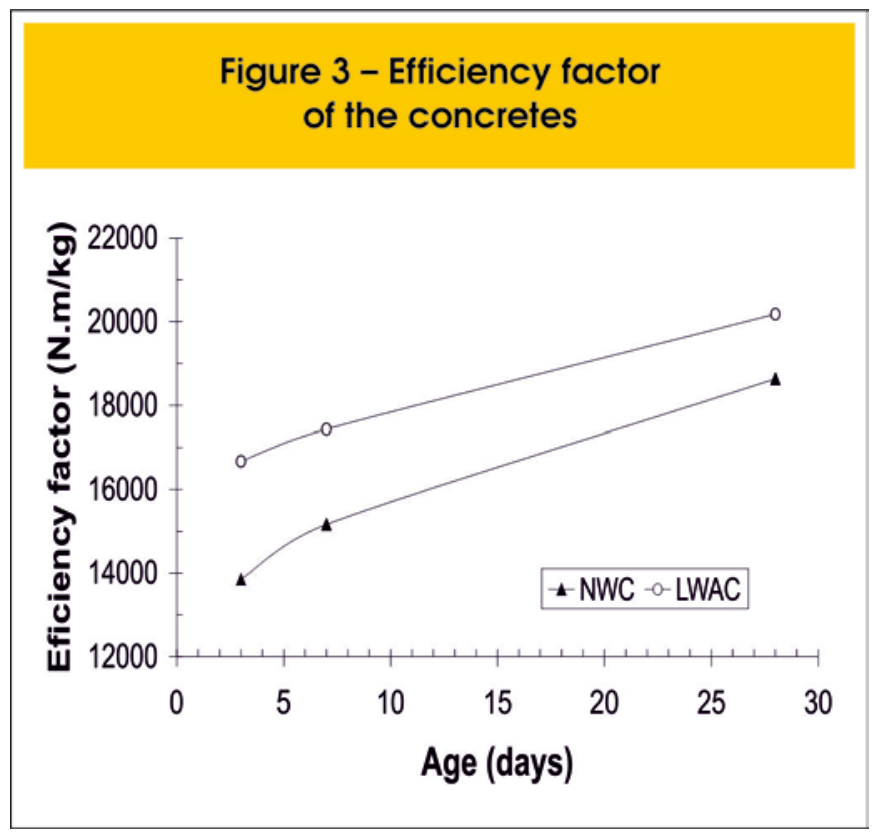

Table 6 - Evolution rates of properties related to the efficiency factor

\section{Properties}

NWC - strength (MPa)

NWC - density $\left(\mathrm{kg} / \mathrm{m}^{3}\right)$

NWC - efficiency factor (N.m/kg)

LWAC - strength (MPa)

LWAC - density $\left(\mathrm{kg} / \mathrm{m}^{3}\right)$

LWAC - efficiency factor (N.m/kg)

\begin{tabular}{|ccc|}
\multicolumn{3}{c}{ Age (days) } \\
\hline 3 & 7 & 28 \\
32.5 & 35.9 & 44.9 \\
2346 & 2367 & 2410 \\
13853 & 15167 & 18631 \\
26.9 & 28.6 & 33.2 \\
1614 & 1641 & 1645 \\
16667 & 17428 & 20182
\end{tabular}

\section{Percentages}

NWC - Compressive strength evolution rate (\%)

10.46

38.15

NWC - Density evolution rate (\%)

0.90

2.73

NWC - Efficiency factor evolution rate (\%)

9.48

34.49

LWAC - Compressive strength evolution rate (\%)

6.32

23.42

LWAC - Density evolution rate (\%)

$1.67 \quad 1.92$

LWAC - Efficiency factor evolution rate (\%)

4.57

21.09

Difference between the efficiency factor of

LWAC and NWC

$20.31 \quad 14.91$


Figure 4 - Pozzolanic analysis of the expanded clay powder

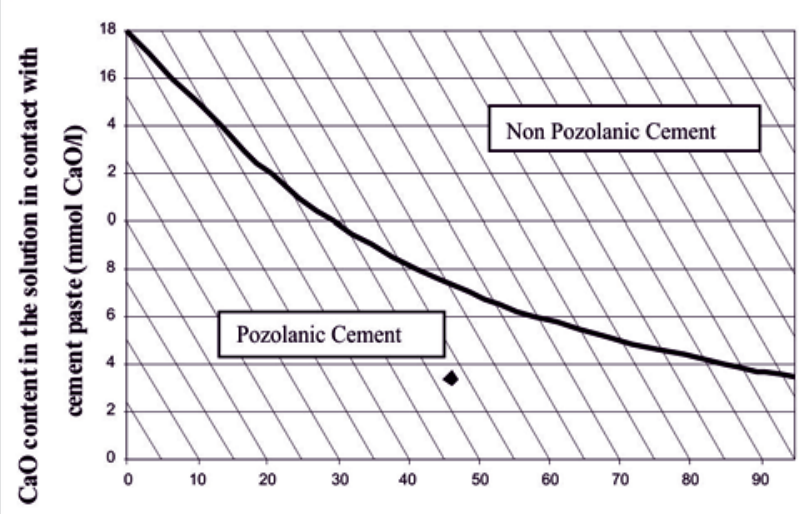

analyzed concretes are neither linear nor parallel, underlining the importance of evaluating the behavior of concretes when correlating intrinsically related characteristics such as density and strength up to the age of 28 days, at which point they stabilize.

The properties of concrete can be improved by physical or chemical processes that take place in the transition zone between the lightweight aggregate and the cement matrix. The chemical processes are associated with the pozzolanic activity of this aggregate and with the deposition of $\mathrm{CH}$ in voids in the transition zone, while the physical interactions are associated with the mechanical interlocking of these aggregates with the cement paste [5]. Therefore, the higher efficiency factor of LWAC indicates that its properties improved in response to these phenomena in the transition zone between the lightweight aggregate and the cement matrix. The existence of the pozzolanic activity of the dust adhering to the surface of the expanded clay in contact with the cement, which was evaluated by the chemical method at 7 days of age, was confirmed as indicated by the results depicted in Figure [4].

The pozzolanic analysis of the expanded clay powder by the chemical method fell below the limit curve, which is an area that belongs to pozzolanic material. This finding indicates that there was pozzolanic activity between the silicates of the powder adhered on the surface of the expanded clay and the $\mathrm{CH}$ of the cement matrix, forming C-S-H (calcium silicate hydrate). The analysis also revealed that the LWAC showed higher rates of pozzolanic activity than the NWC.

Figures [5a] and [5b] depict, respectively, the penetration of the cement paste and the products of cement hydration inside the shell of the surface pores of the expanded clay aggregate, increasing the bond by mechanical interlocking.

\subsection{Static and dynamic modulus of elasticity}

Figure [6] shows the stress-strain curves obtained from the concretes with an estimated strength of $40 \mathrm{MPa}$. The values represent the mean results obtained from the tests on the specimens. LWAC was found to present a behavior similar to NWC, despite its lower compressive strength and lower modulus of elasticity.

Table [7] lists the results of the static and dynamic modulus of elasticity of NWC and LWAC test specimens, as well as the calculation moduli using an empirical equation.

Table [7] shows the results of the static, dynamic and empirical modulus of elasticity. The latter modulus was calculated using Equation [1]. The values obtained for the static modulus of elasticity were lower than those found by the other methods. This reduction represented $14 \%$ for NWC and $12 \%$ for LWAC when compared to the dynamic modulus. This difference can be explained by the

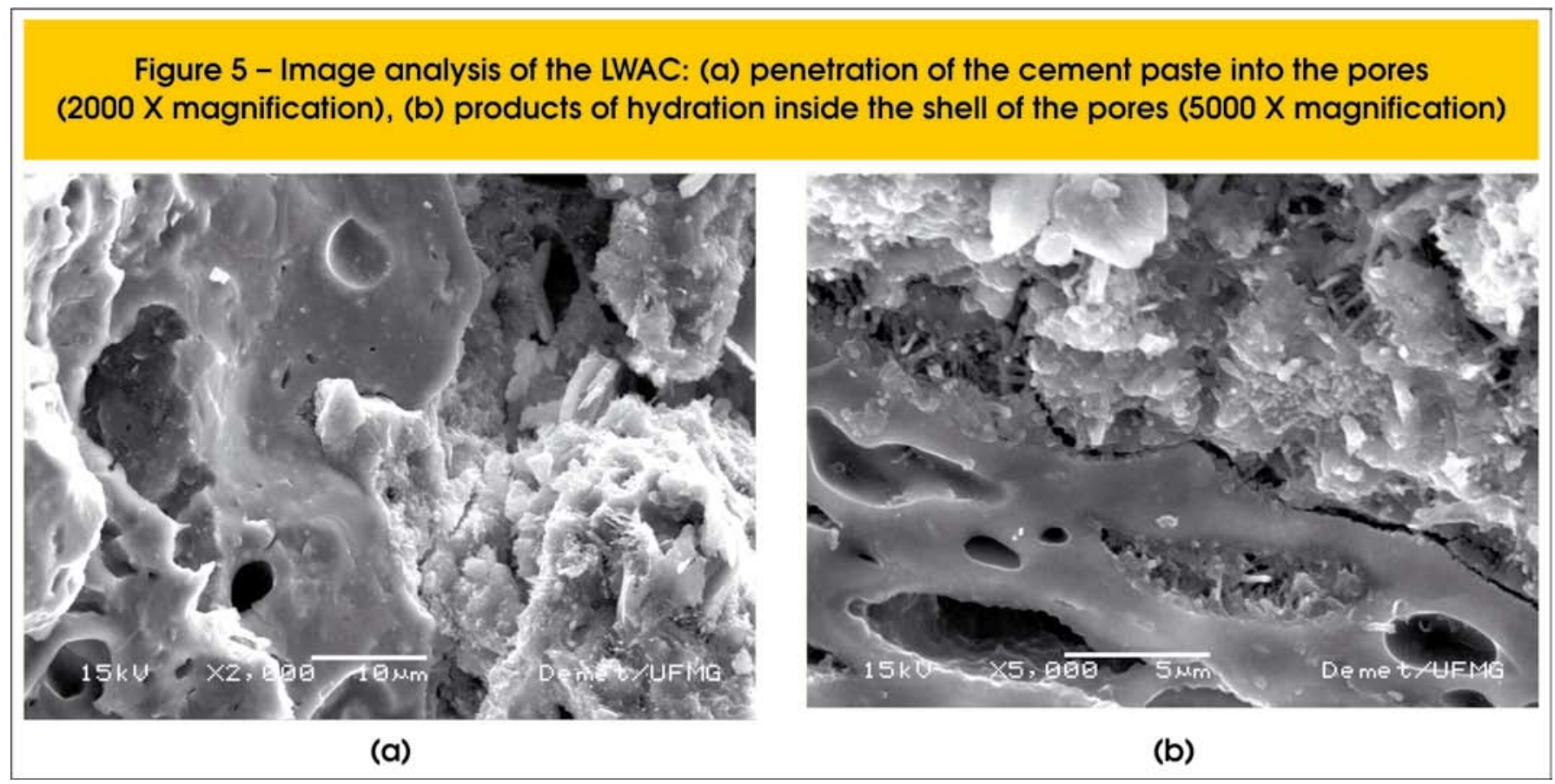




\section{Figure 6 - Stress/strain of the concretes}

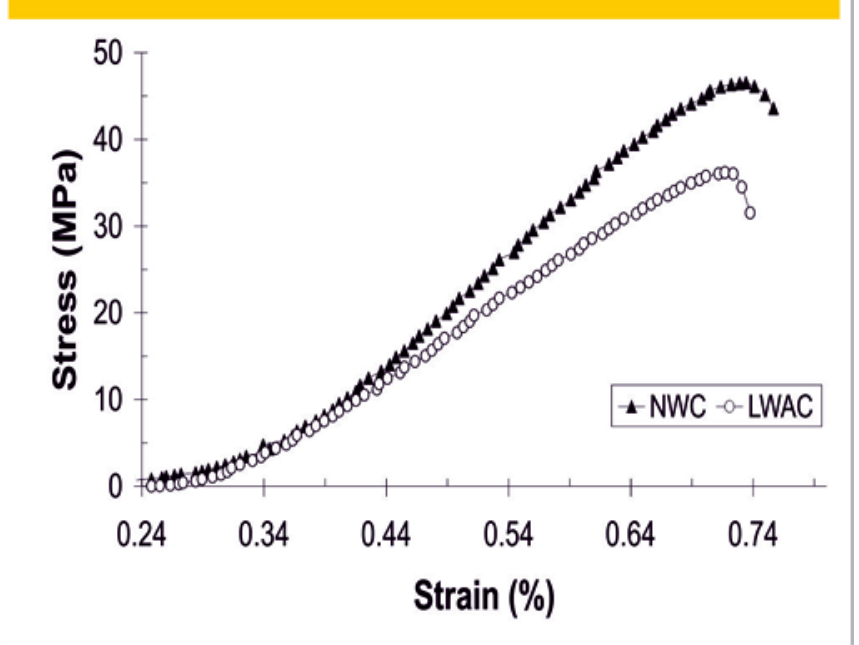

greater precision of the method used to determine the static modulus of elasticity. As seen previously, this method determines the modulus from the stress vs. strain diagram, and is therefore more representative than the others. The values obtained for the static modulus of elasticity of LWAC ranged from $15 \mathrm{GPa}$ to $17 \mathrm{GPa}$, and were on average one third of the values obtained for NWC, which is compatible with results found by other authors [1]. This indicates the greater capacity of LWAC than of NWC to absorb small deformations such as those caused by shrinkage, which can reduce internal stresses and the formation of microcracks.

\section{Conclusions}

The LWAC presented a lower compressive strength than the NWC with the same mixture proportion and an estimated compressive strength of $40 \mathrm{MPa}$. The lower compressive strength of LWAC in this mixture proportion can be explained by the lower strength of expanded clay when compared with that of limestone aggregate. Nevertheless, from the standpoint of density and compressive strength, the LWAC analyzed in this study can be classified as a structural concrete.

Despite its lower compressive strength, the LWAC presented a higher efficiency factor than the NWC. This behavior of LWAC in- dicates that its properties improved in response to physical and chemical phenomena inside the concrete. The chemical phenomenon was the pozzolanic activity of the powder adhering to the expanded clay surface, while the physical phenomenon was the mechanical interlocking between the expanded clay and the hydration products in the cement paste.

The values obtained for the static modulus of elasticity of LWAC were on average one third of the values obtained for NWC, indicating the greater capacity of LWAC to absorb small deformations such as those caused by shrinkage, which can reduce internal stresses and microcrack formation and increase the service life of lightweight concrete when compared to that of NWC.

\section{Acknowledgements}

The authors thank CINEXPAN Ltda. for supplying the expanded clay, HOLCIM S.A for supplying the cement (CPV ARI-PLUS), CAPES (Coordination of Improved of Personal of Superior Level) for the financial support, UFMG (Federal University of Minas Gerais) and CEFET-MG (Federal Center of Technological Education of Minas Gerais), for the financial and infrastructure support for the accomplishment of this work.

\section{References}

[01] Short, A.; Kinniburgh, W. Lightweight Concrete, London: C.R. Books Limited, 1ed, 1963, 511 p.

[02] Coutinho, A. S. Fabrico e Propriedades do Betão, Lisboa: LNEC, 2ed, vol 1, 1988, 400 p.

[03] CALIXTO, J. M.; GOMES, L. C.; PIMENTA, R. J.; MONTEIRO, R. C.; MELO, C.; ROCHA, G. G. Concreto Estrutural Leve: Exemplo de aplicação. In: Congresso Brasileiro do Concreto, $43^{\circ}$, Foz do Iguaçu, 2001, Anais, Paraná, 2001, v.1, 14p.

[04] Zhang M, Chia KS. Water permeability and chloride penetrability of high-strength lightweight aggregate concrete, Cement and Concrete Research, 32, 2001; p. 639-645.

[05] Wasserman R, Bentur A. Interfacial Interactions in Lightweight Aggregate Concrete and Their Influence on the Concrete Strength, Cement and Concrete Composites, 18, 1996; p. 67-76.

[06] Moravia WG, Oliveira CAS, Gumieri AG, and Vasconcelos WL. Caracterização microestrutural da argila expandida para aplicação como agregado em

\section{Table 7 - Static and dynamic modulus of elasticity of the analyzed concretes}

\begin{tabular}{|c|c|c|c|c|}
\hline \multirow{2}{*}{$\begin{array}{l}\text { Strength } \\
\text { (MPa) }\end{array}$} & \multirow[t]{2}{*}{ Specimens } & \multicolumn{3}{|c|}{$\begin{array}{l}\text { Modulus of elasticity } \\
\text { (GPa) }\end{array}$} \\
\hline & & Static & Dynamic & Empiric \\
\hline 46.6 & NWC & 25.1 & 29.1 & 34.7 \\
\hline 33.4 & LWAC & 16.0 & 18.2 & 16.6 \\
\hline
\end{tabular}


concreto estrutural leve. Cerâmica, 52, 2006;

p. 193-199.

[07] Associação Brasileira de Normas Técnicas,

NBR 7211 - Agregados para concreto -

Especificaçao. ABNT, Rio de Janeiro, 2005, 11 p.

[08] Mehta, PK; Monteiro, PJM. Concreto: Estrutura,

Propriedades e Materiais. 1.ed. São Paulo:

PINI, 1994. 581p.

[09] Helene PRL, Terzian P. Manual de Dosagem e

Controle do Concreto, São Paulo: PINI, 1992, 349 p.

[10] Associação Brasileira de Normas Técnicas,

NBR 5738 - Moldagem e cura de corpos de prova

cilíndricos ou prismáticos de concreto - procedimento.

ABNT, Rio de Janeiro, 1994, $9 \mathrm{p}$

[11] Associação Brasileira de Normas Técnicas, NBR 5739 - Concreto - ensaio de compressão de corpos de prova cilíndricos. ABNT, Rio de Janeiro, 1994, $4 \mathrm{p}$.

[12] Associação Brasileira de Normas Técnicas, NBR 5753

- Cimentos - método de eterminação de atividade pozolânica em cimento Portland pozolânico. ABNT, Rio de Janeiro, 1992, 3 p.

[13] Associação Brasileira de Normas Técnicas, NBR 8522 - Concreto - Determinação do módulo de deformação estática e diagrama - Tensão $x$ deformação. ABNT, Rio de Janeiro, 2982, 3 p.

[14] American Concrete Institute - ACl. Manual of Concrete Practice, Part 3, "Building Code Requirements for Reinforced Concrete", Reported by ACl Committee 318. Detroit, 1992.

[15] American Society For Testing And Materials. Standard Specification for Lightweight Aggregates for Structural Concrete. ASTM C 330 - 77. Philadelphia, 1991.

[16] Associação Brasileira de Normas Técnicas, NBR 6118 - Projeto de estruturas de concreto Procedimentos. ABNT, Rio de Janeiro, 1994, 221 p. 